Vol. 9 (2000): 231-238.

\title{
Maintenance of male sterile germplasm in Brassica rapa by in vitro propagation
}

\author{
Yang-Dong Guo \\ Laboratory of Plant Physiology and Molecular Biology, Department of Biology, \\ FIN-20014 University of Turku, Finland, e-mail: yaguo@utu.fi \\ Tarja Niemelä, Unto Tulisalo \\ Mildola Ltd, Anttila Research Farm, Anttilantie 30, FIN-04300 Tuusula, Finland \\ Seppo Pulli \\ Laboratory of Plant Physiology and Molecular Biology, Department of Biology, \\ FIN-20014 University of Turku, Finland
}

\begin{abstract}
An efficient tissue culture system for plant regeneration, from mature cut branches, was established to maintain male sterile material in Brassica rapa L. The new-growth immature pods from the cut branches were used as explants; they gave better results in callus initiation (37 calli from 25 explants) and shoot formation (17 shoots from 75 explants) than flower buds and branch stems. Auxin [2,4-dichlorophenoxyacetic acid (2,4-D), 2 to $5 \mathrm{mg} \mathrm{l}^{-1}$ ] and cytokinin [6-benzylaminopurine (BA), 2 to $4 \mathrm{mg} \mathrm{l}^{-1}$ ] were essential in callus and shoot formation, respectively. Callus initiation and shoot regeneration capacities were genotype dependent. The regenerated plants were male sterile and were used in breeding programs.
\end{abstract}

Key words: Brassica rapa L., callus, in vitro micropropagation, plant growth regulators, shoots

\section{Introduction}

Plant regeneration from somatic cells is possible either via shoot/root organogenesis or via somatic embryogenesis. Both pathways have resulted in regenerants from numerous species (Lörz et al. 1988). One of the most useful applications of plant tissue culture lies in the possibility of cloning a particular genotype. This can be especially important if the desired plant is a hybrid or an allogamous species, due to the fact that the sexually-derived progeny of these types are no longer identical to the original genotype (Linacero and Vazquez 1990). Clonal propagation of plants is based on the concept of totipotency. It is a prerequisite for most applied uses of plant tissue cultures. Effective plant tissue culture techniques have been developed for several of the economically important species of 
Guo, Y.-D. et al. Maintenance of male sterile material in Brassica rapa

Brassica from explants of leaves, hypocotyls, petioles, stem layers and protoplasts (Bhattacharya and Sen 1980, Li and Kohlenbach 1982, Eapen et al. 1989, Kirti and Chopra 1990).

Turnip rape (Brassica rapa L.) is the most important oil crop in Finland. Cytoplasmic male sterility was used in turnip rape breeding work. This cytoplasmic male sterility (cms), originally found by Ogura (1968), was transferred to $B$. oleracea and B. napus. Male sterile B. napus cybrids were then produced through protoplast fusion (Pelletier et al. 1983) to generate male sterile lines with highly stable male sterility, improved nectar secretion and a high productivity (Pelletier et al. 1987). This OGU-INRA cytoplasmic male sterility was transferred to Brassica rapa by back-crossing. The in vitro propagation method was used to save the male sterile breeding material in this study. This method facilitated recycling of the same sterile A-line (cms) genome and the crossing of it with certain R-lines (fertility restoring) in descending generations in order to study the maternal impact on F1 hybrids.

Brassica rapa is more recalcitrant in tissue culture than other Brassica species. In this study, cut branches were collected, cold treated and forced to induce new buds. Old stems and newgrowth tissues such as flower buds and newgrowth immature pods were then used as explants for in vitro propagation. The best results were achieved from new-growth immature pods of the harvested male sterile plants in callus initiation and shoot regeneration tests. Complete plants were regenerated. Male sterile breeding material was thus maintained via in vitro propagation using immature pods as explants.

\section{Material and methods}

Cut branches from 121 different male sterile breeding line plants, under cross-testing in the greenhouse, were used as explant sources. The greenhouse growth condition for donor plants was $20^{\circ} \mathrm{C} / 17^{\circ} \mathrm{C}$ day/night temperature and a 16 $\mathrm{h}$ photoperiod at $150 \mu \mathrm{mol} \mathrm{m} \mathrm{m}^{-2} \mathrm{~s}^{-1}$ supplemented by fluorescent lamps. The breeding lines included 91451-A, 92549-A, 4001-A, 4002-A and 4003-A, all Mildola's female breeding lines, from Brassica rapa hybrid program. Parkland, an old Canadian variety, was used as a control in this program. All test lines, except for the control, have Ogura radish (OGU-INRA) cytoplasmic male sterility.

Vegetative cut branches were stored with stalks in water in a $4^{\circ} \mathrm{C}$ cold room with 8 -h photoperiod at $20 \mu \mathrm{mol} \mathrm{m} \mathrm{m}^{-2} \mathrm{~s}^{-1}$ for one month, then, these cut branches were transferred to a greenhouse to induce new growth. The growth condition for inducing flower buds and immature pods was $25^{\circ} \mathrm{C}$ and a 16 -h photoperiod at $150 \mu \mathrm{mol}$ $\mathrm{m}^{-2} \mathrm{~s}^{-1}$ supplemented by fluorescent lamps. The branch stalks were in tap water and water changed every three days.

Branch stems, flower buds and new-growth immature pods of the harvested branches were surface sterilized in $70(\mathrm{v} / \mathrm{v})$ ethanol for $1 \mathrm{~min}$, followed by $5 \mathrm{~min}$ in a $10 \%$ sodium hypochlorite solution containing one drop of Tween-20 and then rinsed three times with sterile distilled water. The following explants were used to initiate cultures on semi-solid medium: the suitable size of flower bud was between 3 and $6 \mathrm{~mm}$; branch stem explants were $3 \mathrm{~mm}$ thick transverse sections; 5-10 mm long immature pods containing embryos, were cut into 4 to $5 \mathrm{~mm}$ explants.

The explants were plated on semi-solid callus induction media. The culture medium consisted of $\mathrm{B}_{5}$ (Gamborg et al. 1968) macro- and micro-nutrients, inositol $100 \mathrm{mg} \mathrm{l}^{-1}$, nicotinic acid $1 \mathrm{mg} \mathrm{l}^{-1}$, pyridoxine-HCl $1 \mathrm{mg} \mathrm{l}^{-1}$, thiamine$\mathrm{HCl} 5 \mathrm{mg} \mathrm{l}^{-1}$, L-glutamine $2 \mathrm{mg} \mathrm{l}^{-1}$, L-alanine 10 $\mathrm{mg} \mathrm{l}^{-1}$, casein hydrolysate $200 \mathrm{mg} \mathrm{l}^{-1}$, glycine 2 $\mathrm{mg} \mathrm{l}^{-1}$, sucrose $(3 \%, \mathrm{w} / \mathrm{v})$ and Phytagel ${ }^{\mathrm{TM}}(0.3 \%$, $\mathrm{w} / \mathrm{v})$. All media used in these experiments were sterilized by autoclaving at $1.1 \mathrm{~kg} / \mathrm{cm}^{2}$ and $120^{\circ} \mathrm{C}$ for $20 \mathrm{~min}$. The explants were cultured in $9 \mathrm{~cm}$ Petri dishes containing $35 \mathrm{ml}$ of sterile medium in darkness at $27^{\circ} \mathrm{C}$. The effect of growth regulators on callus induction was investigated by culturing explants on induction media supple- 
Vol. 9 (2000): 231-238.

mented with different concentrations of auxin [2,4-dichlorophenoxyacetic acid (2,4-D), 1-6 mg $\mathrm{l}^{-1}$ ] combined with $0.1 \mathrm{mg} \mathrm{l}^{-1}$ kinetin (6-furfurylaminopurine). Each treatment consisted of three replicates each with 25 explants.

After a four week induction period, the calli were subcultured onto the same medium for three to four weeks. Calli between 5 and $10 \mathrm{~mm}$ in size, were transferred to shoot regeneration medium consisted of $\mathrm{B}_{5}$ basal components containing 6-benzylaminopurine (BA) $\left(1-5 \mathrm{mg} \mathrm{l}^{-1}\right)$ in combination with one of three low levels of auxin, naphthaleneacetic acid (NAA) $0.2 \mathrm{mg} \mathrm{l}^{-1}, 3$ indoleacetic acid (IAA) $0.2 \mathrm{mg} \mathrm{l}^{-1}$ or 2,4-D 0.1 $\mathrm{mg} \mathrm{l}^{-1}$. Shoot regeneration was maintained at a light intensity of $50 \mu \mathrm{mol} \mathrm{m} \mathrm{m}^{-2} \mathrm{~s}^{-1}$ and a 16 -h photoperiod supplemented by fluorescent lamps and a temperature of $25^{\circ} \mathrm{C}$. For rooting, regenerated shoots were transferred to half-strength, hormone-free $\mathrm{B}_{5}$ medium at conditions same as that for shoot regeneration. The rooted plantlets were transferred into $15 \mathrm{~cm}$ plastic pots containing peat/sand mixture to a greenhouse under controlled conditions employing $25^{\circ} \mathrm{C} / 18^{\circ} \mathrm{C}, 16 \mathrm{~h}$ photoperiod. The light intensity was about 150 $\mu$ molm $^{-2} \mathrm{~s}^{-1}$ supplemented by fluorescent lamps. Plantlets were covered with glass beakers during the first week of acclimatization to prevent desiccation of plants.

\section{Results and discussion}

\section{Explant sources}

There were differences in callus induction and shoot propagation capacities among the three sources of explants (Table 1). The callus initiated from new-growth immature pods was solid, compact and grew rapidly (Fig. 1a). The callus from flower buds grew slowly, and was loose. The callus from branch stems grew slowly, turned brown in colour and died after several subcultures. Green shoots could not be obtained from branch stem derived callus. Callus induc-
Table 1 . The number of calli formed and shoots regenerated in turnip rape male sterile breeding line (4003A-26). The modified $\mathrm{B}_{5}$ medium containing $5 \mathrm{mg} \mathrm{l}^{-1} 2,4-\mathrm{D}$ and 0.1 $\mathrm{mg} \mathrm{l}^{-1}$ kinetin was used in callus induction. In shoot regeneration, $\mathrm{B}_{5}$ medium with $2 \mathrm{mg} \mathrm{l}^{-1} \mathrm{BA}$ and $0.1 \mathrm{mg} \mathrm{l}^{-1} 2$,4-D was employed. Data is the average of three replicates, 25 explants per replicate.

\begin{tabular}{lcc}
\hline Explant source & No. callus \pm SD* & No. shoot (total) \\
\hline Immature pod & $37 \pm 9$ & 17 \\
Flower bud & $16 \pm 2$ & 5 \\
Branch stem & $7 \pm 3$ & 0 \\
\hline
\end{tabular}

$* \mathrm{SD}=$ standard deviation.

2,4-D = 2,4-dichlorophenoxyacetic acid

Kinetin = 6-furfurylaminopurine

$\mathrm{BA}=6$-benzylaminopurine

tion and shoot formation was much better from immature pod explants than from flower bud and stem explants.

The explant source acts an important role in micropropagation of Brassica species. In Brassica rapa ssp. Pekinensis, the successful explant for micropropagation was the cotyledon (Kuo and Tsay 1977), it represented a significant improvement in regeneration of Chinese cabbage in comparison with axillary buds that were cultured. Young hypocotyl explants were used for somatic embryogenesis and plant regeneration in six Brassica species (Dietert et al. 1982, Yang et al. 1991, Narasimhulu et al. 1992). Hypocotyl segments, stem and leaf explants from seedlings were used in somatic embryogenesis in Brassica nigra (Narasimhulu et al. 1992). In Brassica napus, in vitro plant formation was induced from internodal segments (Kartha et al. 1974), cotyledon, hypocotyls and stem sections (Khehra and Mathias 1992), axillary buds (Polowick and Sawhney 1991) and thin cell layer explants (Klimaszewska and Keller 1985, Shu and Loh 1991). In the present study, branch stems, flower buds and immature pods were used as explants in micropropagation due to old and wilting donor materials. The immature pods gave the best results for callus induction and plant regeneration.

The age of the donor plant (explant) is a crit- 


\section{AGRICULTURAL AND FOOD SCIENCE IN FINLAND}

Guo, Y.-D. et al. Maintenance of male sterile material in Brassica rapa
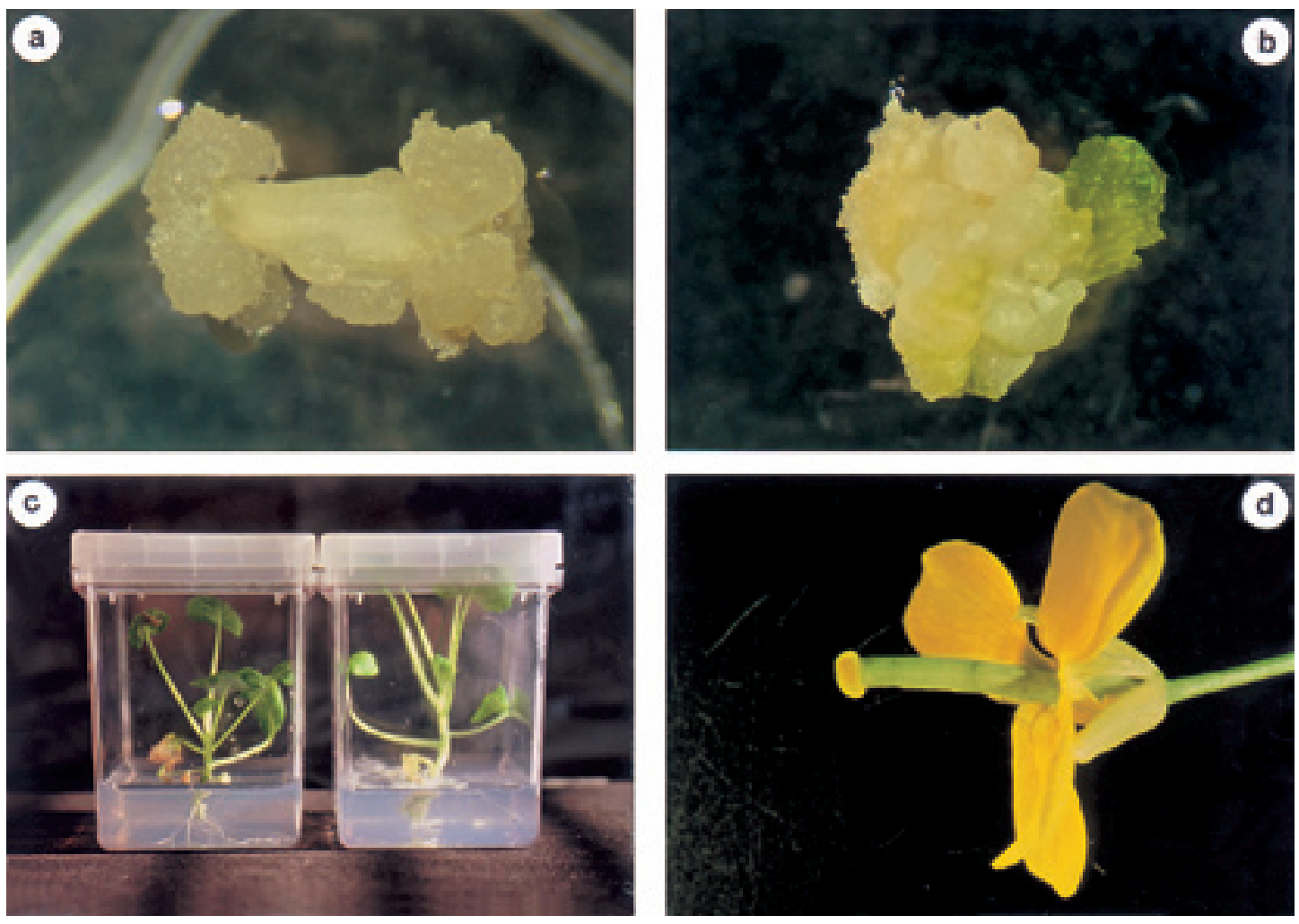

Fig. 1. Callus initiation and shoot regeneration in Brassica rapa male sterile material (4003A-6) using immature pods. The modified $\mathrm{B}_{5}$ medium containing $4 \mathrm{mg} \mathrm{l}^{-1} 2,4-\mathrm{D}$ and $0.1 \mathrm{mg} \mathrm{l}^{-1}$ kinetin was used in callus induction from immature pod. In shoot regeneration, $\mathrm{B}_{5}$ medium with $2 \mathrm{mg} \mathrm{l}^{-1} \mathrm{BA}$ and 2,4-D $0.1 \mathrm{mg} \mathrm{l}^{-1}$ was employed. Abbreviations: 2,4-D = 2,4-dichlorophenoxyacetic acid, Kinetin $=6$-furfurylaminopurine, BA $=6$-benzylaminopurine .

(a) Callus initiation from an immature pod explant after two weeks of culture $(8 \mathrm{x})$.

(b) Shoot formation from callus in regeneration medium $(8 \mathrm{x})$.

(c) Well developed plantlet from immature pod propagation.

(d) A flower from regenerated plant with male sterile character.

ical factor affecting callus initiation and shoot regeneration in Brassica species (Yang et al. 1991). Generally, young tissue is used as an optimal explant, the old explants are always avoided in plant tissue culture.

In the present study, 121 male sterile breeding line plants were used as explant sources. These donor plants were under cross-testing in the greenhouse at the time that the branches were cut. Only a few breeding lines were selected for micropropagation as determined by their agronomic characteristics and crossing ability in de- scending generations in order to study the maternal impact on F1 hybrids. Therefore, the cut branches were stored (for one month at $4^{\circ} \mathrm{C}$ ) awaiting greenhouse test results. Using this method, time and labour could be saved. However, these cut branches were old and conventional micropropagation techniques could not be applied.

After branches were moved to the greenhouse at $25^{\circ} \mathrm{C}$, the new-growth immature pods and new-growth flower buds became usable. These new-growth organs with active metabolism 
Vol. 9 (2000): 231-238.

Fig. 2. Effect of auxin (2,4-D = dichlorophenoxyacetic acid) concentration combined with $0.1 \mathrm{mg}$ $\mathrm{1}^{-1}$ kinetin (6-furfurylaminopurine) on callus initiation from immature pod of turnip rape in vitro propagation. Four replicates, 25 explants per replicate. Vertical bars indicate the standard error of the mean.

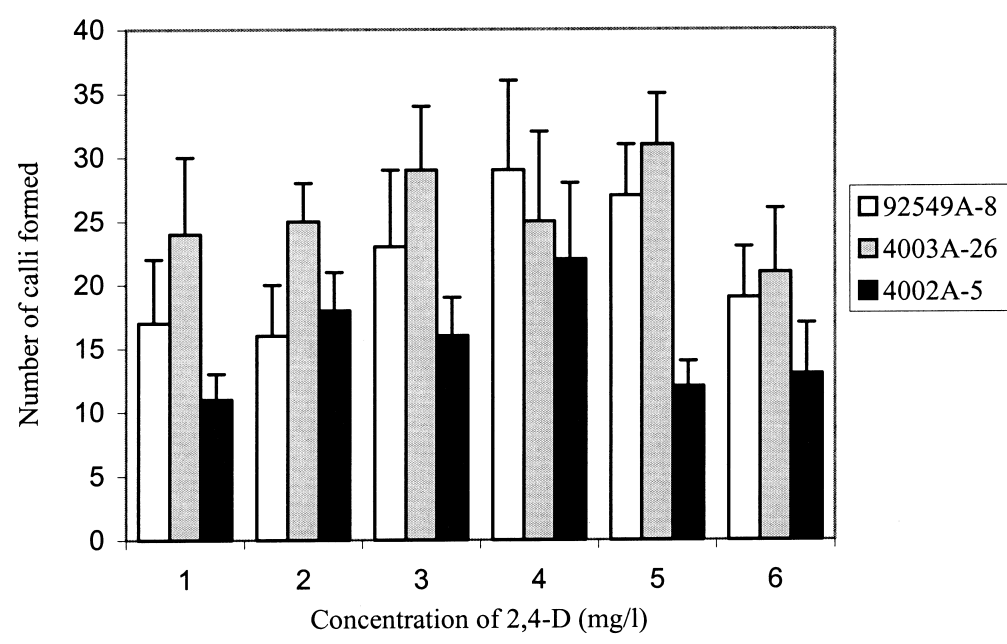

yielded calli and shoots with a relatively high regularity.

\section{Influence of 2,4-D concentration on callus initiation}

$\mathrm{B}_{5}$ basal medium (Gamborg et al. 1968) was used as callus induction and shoot regeneration medium in this study. Auxin and cytokinin are essential in callus induction and shoot formation, respectively. In this study, 2,4-D was used as the auxin at $1 \mathrm{mg} \mathrm{l}^{-1}, 2 \mathrm{mg} \mathrm{l}^{-1}, 3 \mathrm{mg} \mathrm{l}^{-1}, 4 \mathrm{mg} \mathrm{l}^{-1}, 5 \mathrm{mg}$ $\mathrm{l}^{-1}, 6 \mathrm{mg} \mathrm{l}^{-1}$ for callus induction, combined with a low level of cytokinin (kinetin $0.1 \mathrm{mg} \mathrm{l}^{-1}$ ). Concentrations of 2,4-D between 2 and $5 \mathrm{mg} \mathrm{l}^{-1}$ gave the best result for callus induction. However, there was a genotype difference. For clone 92549A-8, 4-5 $\mathrm{mg} \mathrm{l}^{-1}$ 2,4-D promoted the callus initiation effectively whereas for clones 4003A26 and 4002A-5, the best dosages of 2,4-D were $5 \mathrm{mg} \mathrm{l}^{-1}$ and $4 \mathrm{mg} \mathrm{l}^{-1}$, respectively (Fig. 2). The importance of 2,4-D in callus initiation and growth in Brassica species has been recognized (Bajaj and Nietsch 1975, Dietert et al. 1982, Shu and Loh 1991). Dietert et al. (1982) reported that a high level of 2,4-D may inhibit callus growth, but the presence of low levels of this auxin is required for callus proliferation and for inhibition of root development in certain cultivars of $B$. oleracea and B. napus.

\section{Influence of $B A$ on shoot formation}

The function of BA in Brassica species micropropagation has been reported. Deng et al. (1991) described that in Chinese cabbage (B. rapa ssp. Pekinensis), the concentration of BA which promoted the highest rate of shoot induction showed clonal variation and was in the range of 44.4 to 177.6 $\mu \mathrm{M}$. In B. napus, BA alone $(5 \mu \mathrm{M})$ induced multiple shoot formation on stem explants (Kartha et al. 1974). In this work, the combinations of auxin (NAA $0.2 \mathrm{mg} \mathrm{l}^{-1}$, IAA $0.2 \mathrm{mg} \mathrm{l}^{-1}$ and 2,4-D $0.1 \mathrm{mg} \mathrm{l}^{-1}$ ) and cytokinin (BA 1-5 $\mathrm{mg} \mathrm{l}^{-1}$ ) were investigated. In a shoot regeneration experiment using clone $4003 \mathrm{~A}-8$, and in the presence of NAA $0.2 \mathrm{mg} \mathrm{l}^{-1}$, IAA $0.2 \mathrm{mg} \mathrm{l}^{-1}$ or 2,4-D $0.1 \mathrm{mg}^{-1}$, the optimal BA concentrations were $3 \mathrm{mg} \mathrm{l}^{-1}, 4 \mathrm{mg} \mathrm{l}^{-1}$ and $2 \mathrm{mg} \mathrm{l}^{-1}$, respectively (Fig. 3).

Shoots could be obtained after 4 to 6 weeks when calli were cultured on regeneration medium (Fig. 1b). When the shoots were $1 \mathrm{~cm}$ high, they were cut from callus and subcultured to the 


\section{AGRICULTURAL AND FOOD SCIENCE IN FINLAND}

Guo, Y.-D. et al. Maintenance of male sterile material in Brassica rapa

Table 2. Genotype effect on callus and shoot formation in B. rapa male sterile breeding materials propagation. Immature pods were used as explants in callus induction experiments. The modified $\mathrm{B}_{5}$ medium containing $4 \mathrm{mg}^{-1}$ 2,4-D and $0.1 \mathrm{mg} \mathrm{l}^{-1}$ kinetin was used in callus induction. In shoot regeneration, $\mathrm{B}_{5}$ medium with $2 \mathrm{mg} \mathrm{l}^{-1} \mathrm{BA}$ and 0.1 $\mathrm{mg}^{-1} 2,4-\mathrm{D}$ was employed. Means \pm standard deviation are from three replicates, 25 explants per replicate.

\begin{tabular}{|c|c|c|c|}
\hline \multicolumn{2}{|c|}{ Breeding lines } & \multirow{2}{*}{$\begin{array}{l}\text { No. callus/dish } \\
\qquad 31 \pm 3^{*}\end{array}$} & \multirow{2}{*}{$\begin{array}{c}\begin{array}{c}\text { Shoot formation } \\
\text { (total) }\end{array} \\
5\end{array}$} \\
\hline $91451 \mathrm{~A}$ & -1 & & \\
\hline & -4 & $25 \pm 3$ & 11 \\
\hline & -5 & $17 \pm 3$ & 0 \\
\hline & -6 & $34 \pm 4$ & 0 \\
\hline & -11 & $20 \pm 4$ & 1 \\
\hline & -12 & $15 \pm 5$ & 25 \\
\hline & -14 & $16 \pm 4$ & 12 \\
\hline & -16 & $24 \pm 4$ & 3 \\
\hline & -19 & $24 \pm 6$ & 0 \\
\hline & -20 & $26 \pm 8$ & 7 \\
\hline & -21 & $24 \pm 2$ & 10 \\
\hline & -23 & $39 \pm 1$ & 6 \\
\hline & -24 & $24 \pm 5$ & 0 \\
\hline & -25 & $9 \pm 3$ & 5 \\
\hline & -28 & $21 \pm 6$ & 0 \\
\hline \multirow[t]{8}{*}{ 92549A } & -5 & $17+4$ & 10 \\
\hline & -6 & $15 \pm 3$ & 0 \\
\hline & -8 & $33 \pm 3$ & 7 \\
\hline & -9 & $25 \pm 2$ & 3 \\
\hline & -11 & $37 \pm 3$ & 2 \\
\hline & -12 & $20 \pm 6$ & 11 \\
\hline & -14 & $18 \pm 1$ & 15 \\
\hline & -15 & $25 \pm 9$ & 0 \\
\hline \multirow[t]{12}{*}{ Parkland } & -3 & $23+5$ & 4 \\
\hline & -4 & $7 \pm 3$ & 0 \\
\hline & -5 & $14 \pm 4$ & 0 \\
\hline & -6 & $30 \pm 3$ & 5 \\
\hline & -7 & $25 \pm 5$ & 11 \\
\hline & -8 & $33 \pm 4$ & 4 \\
\hline & -9 & $24 \pm 6$ & 17 \\
\hline & -10 & $28 \pm 7$ & 5 \\
\hline & -13 & $24 \pm 3$ & 0 \\
\hline & -14 & $20 \pm 3$ & 13 \\
\hline & -15 & $33 \pm 4$ & 7 \\
\hline & -16 & $34 \pm 6$ & 9 \\
\hline \multirow[t]{2}{*}{$4001 \mathrm{~A}$} & -1 & $25 \pm 7$ & 5 \\
\hline & -3 & $24 \pm 4$ & 15 \\
\hline \multirow[t]{5}{*}{$4002 \mathrm{~A}$} & -2 & $35 \pm 3$ & 5 \\
\hline & -3 & $31 \pm 8$ & 7 \\
\hline & -4 & $27 \pm 8$ & 0 \\
\hline & -5 & $25 \pm 4$ & 24 \\
\hline & -6 & $37 \pm 2$ & 7 \\
\hline
\end{tabular}

continued on next column continued from preceding column

\begin{tabular}{|c|c|c|c|}
\hline Breedin & nes & No. callus/dish & Shoot formation \\
\hline & -7 & $33 \pm 5$ & 7 \\
\hline & -10 & $19 \pm 3$ & 5 \\
\hline & -14 & $23 \pm 3$ & 8 \\
\hline & -15 & $18 \pm 1$ & 28 \\
\hline & -17 & $20 \pm 4$ & 9 \\
\hline & -18 & $31 \pm 3$ & 0 \\
\hline & -20 & $28 \pm 6$ & 0 \\
\hline & -22 & $27 \pm 9$ & 5 \\
\hline 4003A & -1 & $25 \pm 3$ & 0 \\
\hline & -5 & $23 \pm 9$ & 6 \\
\hline & -6 & $31 \pm 8$ & 17 \\
\hline & -7 & $17 \pm 4$ & 0 \\
\hline & -8 & $25 \pm 9$ & 29 \\
\hline & -10 & $25 \pm 5$ & 4 \\
\hline & -14 & $24 \pm 1$ & 15 \\
\hline & -16 & $13 \pm 3$ & 0 \\
\hline & -17 & $35 \pm 3$ & 3 \\
\hline & -18 & $23 \pm 3$ & 1 \\
\hline & -19 & $26 \pm 2$ & 0 \\
\hline & -20 & $15 \pm 3$ & 10 \\
\hline & -21 & $31 \pm 4$ & 3 \\
\hline & -22 & $23 \pm 6$ & 14 \\
\hline & -25 & $34 \pm 3$ & 0 \\
\hline & -26 & $35 \pm 2$ & 8 \\
\hline
\end{tabular}

* $\mathrm{SD}=$ standard deviation.

2,4-D = 2,4-dichlorophenoxyacetic acid

Kinetin $=6$-furfurylaminopurine

$\mathrm{BA}=6$-benzylaminopurine

same regeneration medium. The shoots were transferred to a culture jar containing halfstrength, hormone-free $\mathrm{B}_{5}$ medium for rooting when they were over $2.5 \mathrm{~cm}$ high (Fig. 1c). The regenerated plants grew normally and had male sterile character (Fig. 1d). All the clones showed a high degree of phenotypic uniformity within the clone.

\section{Genotype effect on callus and shoot formation}

Among 121 branches, callus was initiated from 66 and shoots from 48 branches which indicates a genotype difference in propagation ability of 
Vol. 9 (2000): 231-238.

Fig. 3. Effect of hormone combinations on shoot formation in $\mathrm{B}$. rapa $(4003 \mathrm{~A}-8)$ in vitro propagation. Means are from four replicates, 25 explants per replicate. Vertical bars indicate the standard error of the mean.

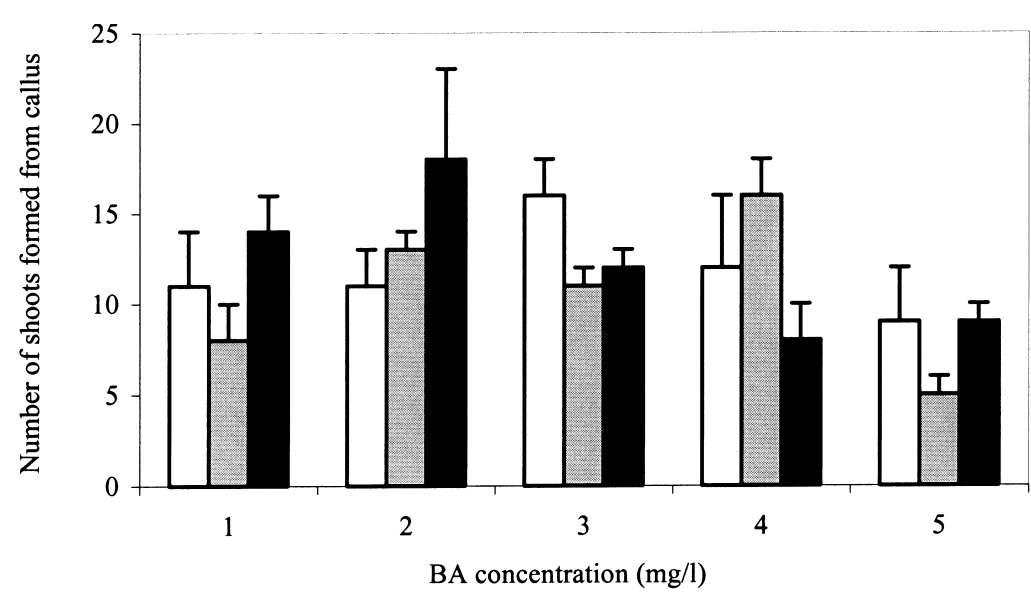

口NAA, $0.2 \mathrm{mg} / \mathrm{l} \quad$ IAA, $0.2 \mathrm{mg} / \mathrm{l} \quad$ 2,4-D, $0.1 \mathrm{mg} / \mathrm{l}$
B. rapa (Table 2). The callus initiation and shoot regeneration capacities were genotype dependent in this study.
Acknowledgments. We thank Mr. Jukka Karhu for technical assistance. This work was supported by Mildola oy and the Finnish Ministry of Agriculture and Forestry.

\section{References}

Bajaj, Y.P.S. \& Nietsch, P. 1975. In vitro propagation of Red Cabbage (Brassica oleracea L. var. capitata). Journal of Experimental Botany 26: 883-890.

Bhattacharya, N.M. \& Sen, S.K. 1980. Production of plantlets through somatic embryogenesis in Brassica campestris. Zeitschrift für Pflanzenphysiologie 99: 357-361.

Deng, S.Y., Heap, I.M. \& Klein, T.A. 1991. In vitro vegetative propagation of Chinese cabbage. Plant Cell, Tissue and Organ Culture 26: 135-139.

Dietert, M.F., Barron, S.A. \& Yoder, O.C. 1982. Effects of genotype on in vitro culture in the genus Brassica. Plant Science Letters 26: 233-240.

Eapen, S., Abraham, V., Gerdemann, M. \& Schieder, O. 1989. Direct somatic embryogenesis, plant regeneration and evaluation of plants obtained from mesophyll protoplasts of Brassica juncea. Annales of Botany 63: 369-372.

Gamborg, O.L., Miller, R.A. \& Ojima, K. 1968. Nutrient requirements of suspension cultures of soybean root cells. Experimental Cell Research 50: 151-158.

Kartha, K.K., Gamborg, O.L. \& Constabel, F. 1974. In vitro plant formation from stem explants of Rape (Brassica napus cv. Zephyr). Physiologia Plantarum 31: 217-220.

Khehra, G.S. \& Mathias, R.J. 1992. The interaction of genotype, explant and media on the regeneration of shoots from complex explants of Brassica napus $\mathrm{L}$. Journal of Experimental Botany 43: 1413-1418.

Kirti, P.B. \& Chopra, V.L. 1990. Rapid plant regeneration through organogenesis and somatic embryogenesis from cultured protoplasts of Brassica juncea. Plant Cell, Tissue and Organ Culture 20: 65-67.

Klimaszewska, K. \& Keller, W.A. 1985. High frequency plant regeneration from thin cell layer explants of Brassica napus. Plant Cell, Tissue and Organ Culture 4: 183-197.

Kuo, C.G. \& Tsay, J.S. 1977. Propagating Chinese cabbage by axillary bud culture. HortScience 12: 456457.

Li, L.C. \& Kohlenbach, H.W. 1982. Somatic embryogenesis in quite a direct way in cultures of mesophyll protoplasts of Brassica napus L. Plant Cell Reports 1: 209-211.

Linacero, R. \& Vazquez, A.M. 1990. Somatic embryogenesis from immature inflorescences of rye. Plant Science 72: 253-258.

Lörz, H., Göbel, E. \& Brown, P. 1988. Advances in tissue culture and progress towards genetic transformation of cereals. Plant Breeding 100: 1-25.

Narasimhulu, S.B., Kirti, P.B., Prakash, S. \& Chopra, V.L. 1992. Somatic embryogenesis in Brassica nigra 


\title{
AGRICULTURAL AND FOOD SCIENCE IN FINLAND
}

Guo, Y.-D. et al. Maintenance of male sterile material in Brassica rapa

(Koch). Journal of Experimental Botany 43: 12031207.

Ogura, H. 1968. Studies on the new male sterility in Japanese radish, with special references to the utilization of this sterility towards the practical raising of hybrid seeds. Memoirs Faculty of Agriculture Kagoshima University 6: 39-78.

Pelletier, G., Primard, C., Veder, F., Chetrit, P., Remy, R., Rousselle, P. \& Renard, M. 1983. Intergenerc cytoplasmic hybridization in Cruciferae by protoplast fusion. Molecular Genome Genetics 191: 244-250.

- , Primard, C., Veder, F., Chetrit, P., Renard, M., Pellan-Delourme, R. \& Mesquida, J. 1987. Molecular, phenotypic and genetic characterization of mitochon- drial recombinants in rapeseed. Proceedings of the 7th International Rapeseed Congress, Poznan, Poland. P. 113-118.

Polowick, P.L. \& Sawhney, V.K. 1991. In vitro floral development of oilseed rape (Brassica napus L.): The effects of $\mathrm{pH}$ and plant growth regulators. Journal of Experimental Botany 42: 1583-1588.

Shu, W. \& Loh, C.S. 1991. Secondary embryogenesis from thin cell layers of Brassica napus ssp. oleifera. New Phytologist 119: 427-432.

Yang, M.Z., Jia, S.R. \& Pua, E.C. 1991. High frequency of plant regeneration from hypocotyls explants of Brassica carinata A. Br. Plant Cell, Tissue and Organ Culture 24: 79-82.

\section{SELOSTUS}

\section{Isästeriilin kevätrypsin geeniaineksen ylläpito in vitro mikroviljelyllä}

\author{
Yang-Dong Guo, Tarja Niemelä, Unto Tulisalo ja Seppo Pulli \\ Turun yliopisto ja Mildola Oy
}

Rypsin (Brassica rapa) solukkoviljely on ristikukkaisten kasvien solukkoviljelyistä vaikeinta. Tämän tutkimuksen tarkoituksena oli pelastaa in vitro mikroviljelyllä valinnassa olevat OGU-INRA isästeriilit CMS-kevätrypsit takaisin valintakiertoon. Tutkimuksessa yritettiin in vitro mikroviljellä tuleentuneen sadon tuottaneiden ja kylmäkäsittelyn saaneiden isästeriilien kasvien lehdistä ja varsista uusia, vihreitä kasveja. Tehtävä epäonnistui, koska tutkittava materiaali ei kyennyt uusiutumaan ikänsä ja mikrobi- ja sienisaastuntansa vuoksi. Jatkotutkimuksessa sama, lähes eloton, tutkimusmateriaali siirrettiin kasvihuoneen optimiolosuhteisiin ja nesteravintoviljelyyn. Kasvit pakotettiin kukintaan, joista edelleen epäkypsät lidut saatiin kasvattamaan kallusta, joka voitiin regeneroida isästeriiliksi lähtömateriaaliksi. Sekä kalluksen kehittyminen että regenerointi todettiin genotyyppiriippuvaisiksi. Kehitetty menetelmä mahdollistaa arvokkaan CMS-materiaalin uudelleenkäytön kypsää satoa vaativan valintaprosessin jälkeen. Ennen kaikkea menetelmä mahdollistaa CMS-äidin uudelleen ja uudelleen testaamisen useiden tekijöiden suhteen, mikä muutoin ristikukkaisella kasvilla olisi mahdotonta. 